\title{
Hausa Language
}

National Cancer Institute

\section{Source}

National Cancer Institute. Hausa Language. NCI Thesaurus. Code C153943.

An Afro-Asiatic Chadic language native to Niger, Nigeria, Ghana, Benin, Cameroon, Ivory Coast, Togo and Sudan. 